\title{
The English Borrowings and the Indonesian-English Code- switching in Two Collections of Blog Short-Stories
}

\author{
Anna Marietta da Silva \\ Department of Applied English Linguistics, Graduate School, Atma Jaya Catholic University of Indonesia, Jakarta, \\ INDONESIA \\ e-mail: anna.silva@atmajaya.ac.id
}

\begin{abstract}
If one has ever read fiction works by prominent Indonesian authors from 1920's Abdul Muis, and Marah Rusli, 1930's Sutan Takdir Alisjahbana and Armijn Pane, 1945's Chairil Anwar and Achdiat K. Mihardja, 1950-1960's Pramoedya Ananta Toer, W. S. Rendra, and N. H. Dini, 1960-1970's Taufik Ismail, Goenawan Moehammad, and Sapardi Djoko Darmono, and compared their work with those of the 1990's Hilman Sriwijaya and Ayu Utami, and the 2000's Hirata, one must have found many differences among the works. More obvious distinction will be discovered if all of the works previously mentioned are contrasted with those of 2000's teen writers like Arunita, Mentari, Andries, and recently Dika, especially in terms of style and vocabulary. The most recent teen fictions have employed much colloquial Indonesian or Malay-Betawi dialect (Djenar, 2008), and English lexical items. This study shows that in Dika's blog short-stories alone, English borrowings and Indonesian-English code-switching were commonly found. English seems to be the third language after the colloquial and standard Indonesian with which the author thinks.
\end{abstract}

Keywords: borrowing, code-switching, blog-stories.

\section{INTRODUCTION}

The phenomena of embedding English to Indonesian texts have received so much attention that a number of Indonesian undergraduate and graduate students whose major is English chose the phenomena of English-Indonesian borrowing (see for example, Srikandi, 2010; Widyaningsih, 2011; Lorania, 2012), and code-switching (see for example, Renata, 2008; Amelia, 2012; Rafiani, 2009; Siregar, 2012) to be the topics of their theses. As for me, the decision to choose writing about this topic may be purely incidental. One of my students, J, told me that she greatly enjoyed Raditya Dika's book because of the author's natural sense of humor. Although I had heard that the author's work was quite phenomenal, I had never been interested in reading his writing, let alone the teen or chic-lit novels, which, in my opinion, do not explore the beauty of language normally characterizing literary works, and are centered on typical teens' lives of school, family, and love (Djenar, 2008, p. 244). Yet, I felt curious, and decided to get the book, which was actually a collection of blog stories.

Blog-stories are stories written on a blog, which is actually one's means to communicate his or her personal ideas or opinion on anything (Leksono, 2008, para. 3). As the stories are not for publication purposes, the style can be informal and does not undergo any editing process, an important requirement of a published work (Lazuardi, 2008, para. 5). Hence, typos are ignored because blog writers naturally do not edit their writings. Raditya Dika's first book was published in 2005, and the title was Kambing Jantan - Sebuah Catatan Harian Pelajar Bodoh [Billy: A Diary of a Stupid Pupil]. The translation is only meant to explain the meaning of the title. It may not capture the humor). It was the first ever published blog-novel in Indonesia. It is a collection of stories based on true stories of the writer's personal experiences previously written on his blog. The stories were written in a comedy genre. Up until 2009 the first book had been reprinted for twenty-three times, or over 10,000 copies. It has even been turned into a comic in 2008, and adapted into a movie in 2009, (The Jakarta Post, 2008). The first work was followed by other works by the same writer, for example, Cinta Brontosaurus [Brontosaurus Love] (2006), Radikus Makan Kakus: Bukan Binatang Biasa [Radikus Eats a Toilet: An Extraordinary Species] (2007), Babi Ngesot: Datang Tak Diundang, Pulang Tak Berkutang [A Disabled Pig: Coming Uninvited, Leaving with No Bra] 
(2008), Marmut Merah Jambu [A Pink Marmot] (2010), and Manusia Setengah Salmon [A HalfSalmon Man] (2011). All works tell about the writer's individual experiences in a humorous style. Comedy seems to be a very successful selling point of Raditya Dika's books (Ismono, 2009, para. 1-3). Thus, Dika's works can be classified into teen fiction because of the segmented readers: teenagers or young people, the use of colloquial Indonesian, and the age of the writer (Djenar, 2008, p. 244).

It was not surprising then that upon reading Raditya Dika's book titled Babi Ngesot, Datang tak Diundang, Pulang tak Berkutang, I was hilariously entertained. It seems that the writer's openness and directness are formulated in humorous and informal style of writing that made many readers, including myself, appreciated his writings (Lazuardi, 2008; Ismono, 2009). Nevertheless, I was frequently 'surprised' by the heavy use of a lot of English words, phrases or sentences inserted into the Indonesian sentences, and even adopted into Indonesian style. It may be the form of the author's rejection to the hegemony of the standard Indonesian promoted by the Centre for the Cultivation and Development of Language, or Pusat Bahasa (Djenar, 2008, pp. 242243). Itmay have characterized today's popular literary work produced by Indonesian young writers. In Dika's books, there have been a lot of English borrowings and code-switching, which can be considered a natural phenomenon once a language comes into contact with other languages (Baker, 2001, p. 101).

Borrowing refers to the integration of words or phrases not belonging to one language into the vocabulary of that language (Romaine, 1995, p. 56; Baker 2001, p. 101). In the context of bilingual speakers, the language that is mostly used is called the base/matrix/host language, while the language that is less activated is called the guest language (Grosjean, 2008, pp. 40). Borrowings can be either caused by the absence of certain words or phrases in one language, such as cultural activities, food, dress, institutions, and concept (Romaine, 1995, p. 142), or the change of topic, situation, and interlocutors in a conversation (Grosjean, 2008, p. 44). Borrowings can be classified into several types:

(1) loanwords, or the original form of words in one language that are used in another language, for example, English lexical items meeting, laptop, printer, basement, final, stop, urgent, and stopwatch which are frequently used in Indonesian language;

(2) loanblends, which show that there is one linguistic item in one language that is used with another linguistic item in another language, for example, Indonesian-English loanblends fotokopi, dipress, didownload, and dicek, and the Indonesian words krah, selop, antre, pabrik and koper which are loanblends from the Dutch words krag, slof, aantreden, fabriek, and koffer, respectively meaning collar, slipper, line up, factory, and suitcase (Sneddon, 2003, pp. 162-164);

(3) loanshift, which means " . . . taking a word in the base language and extending its meaning so that it corresponds to that of a word in the other language," for example, the Indonesian words kerja sama [teamwork] and rumah sakit [hospital] from the Dutch samenwerking and zickenhuis (Sneddon, 2003, p. 166); and,

(4) coinage of new terms consisting of units in one language combined with other units in another language (Romaine, 1995, pp. 56-58), for example, the Indonesian words pra sekolah from Sanskrit prefix pra- and Portuguese sekolah [school], and ilmuwan [scientist] from Arabic ilm (meaning knowledge) and Sanskrit affix -wan (indicating the agent, which has the same function as the English suffix -ist in linguist or -er in adviser) (Sneddon, 2003, pp. 168-171).

Bloomfield (1935) proposed other categories of borrowings: cultural, dialect, and intimate borrowings. Cultural borrowings take place when one language has richer vocabulary and culture than the other language so that particular words must be borrowed from the first language, for example, lexemes such as church, minister, angel, devil, priest and mass were borrowed from Latin into the Old English (pp. 461476). Dialect borrowings can happen to a baby, for instance, who, after listening to the speech of the adults around him, will produce a speech that is actually a combination of all the speeches he/she has heard previously. In that case, power plays an important role. Another example may be the dialect borrowing that occurred during the era of President Soeharto from 1966 until 1998, when highIndonesian rank officials often followed the Javanese dialect of the President in their Indonesian speeches or commentaries; hence the prestigious status of one dialect over the other. The last type of borrowing is the intimate borrowing in which words from the guest language come to the base language of a singlecultural community, for example, the Italian lexical items pizza, spaghetti, lasagna that occur in the English-American vocabulary.

Code-switching is a switch of words, phrase, clause or sentence from one language to another (Baker, 2001, p. 101; Attarriba \& Morier, 2006, pp. 256-257; Edwards, 2006, p. 19; MacSwan, 2006, p. 283; 
Grosjean, 2008, p. 44). Despite the complexity of the motivation of code-switching, it follows particular patterns (Baker, 2001, p. 101; Attarriba \& Morrier, 2006, p. 257; MacSwan, 2006, p. 285). There are also categories of code-switching. Poplack classified codeswitching into tag-switching, inter-sentential and intra-sentential. Tag-switching ". . . involves the insertion of a tag in one language into an utterance ... in the other language;" (as cited in Romaine, 1995, pp. 122-123). The intra-sentential switching includes the insertion of a word, phrase, or clause in one language to a clause or sentence in another language, and the inter-sentential switching is when one switches from one sentence in one language to another sentence in another language (MacSwan, 2006, p. 283). According to Romaine (1995) the types of code-switching lie in a spectrum from the insertion of phonemes to a word, to embedding a sentence in one language to another sentence in another language (p. 124). Code-switching can be either socially or contextually motivated (Baker, 2001, pp. 101-103), and the motivations range from merely the urge to 'fill in' words that are unavailable or unknown in the base language, to the need to highlight and clarify some particular points in a conversation, and to the desire to build a closer or even a distant relationship with others.

There was plenty of research conducted on English borrowings and code-switching to local languages. De Klerk (2006) studied code-switching, borrowing and mixing in a corpus of Xhosa (one of the African languages) English (pp. 604-610). The corpus was the English spoken by Xhosa/English bilinguals consisting of 550,000 transcribed words which were uttered spontaneously in conversational discourse. In the research the matrix language was English, and the embedded language was Xhosa as the informants were interviewed in English. The researcher chose English, not Xhosa, to be the matrix language because she wanted to find out whether the patterns and types of borrowings and code-switching that occurred when English is the embedded language would be projected when the local language is the matrix language. The data showed that the bilinguals mostly did Xhosa lexical borrowing, especially those related to cultural concepts that could not be expressed in English. That borrowing occurred more than code-switching showed the high level of bilingualism of the XhosaEnglish informants.

In addition, O'Malley-Madec (2007) conducted a study on two Irish-speaking communities: F and B in Galway, Ireland. She carried out 25 interviews, out of which only 15 interviews were used, based on Labovian field methods. The data showed that $\mathrm{F}$ community borrowed English nouns mostly. The community also employed English discourse markers to introduce informality to the conversation. Meanwhile, B community had more borrowings for metalinguistic purposes (pp. 499-507).

Besides the above, Kang (2008) investigated the occurrences of English-Chinese Mandarin codeswitching, its patterns and functions in the autobiography of Adeline Yen Mah written in both Mandarin Chinese and English, which she translated herself. The English version was titled Falling Leaves, and the Mandarin Chinese Luoyeguigen 落葉 歸根. The study identified a total of 51 English Chinese code-switching in the Chinese version, and 110 in the English version (pp. 999-1006). In addition there were three French-English, and one CantoneseEnglish code-switching. Code-switching was used to refer to Chinese family terms, and narration in both works. However, in the English version, in addition to the family terms and narration, code-switching also occurred in conversations. The pattern that emerged was the insertion of the English proper nouns, and Chinese characters for Chinese idioms and for chapter titles in the English version. She also found that the autobiographer used code-switching to reveal different identities to different Chinese and American readerships.

Ibhawaegbele and Edokpayi (2012) studied the way three Nigerian novelists, i.e., Achebe in A Man of the People, Cimamanda Adichie in Purple Hibiscus, and Sefi Atta in Everything Good Will Come employed code-mixing for devising stylistic strategies and the importance of using code-mixing or switching in their works. The study exemplified how these novelists used code-switching to show an adjustment to indicate formality, appreciate intimate relationship, express different emotions, have an effective communication, and present the readers with linguistic diversities in Nigeria as well as to protect and preserve them. Ibhawaegbele and Edokpayi concluded that these writers believe that code-mixing or code-switching was one way to introduce and maintain the linguistic richness of Nigeria (2012, pp. 12-18).

In Indonesian context, several graduate students had particular interests in the same linguistic phenomena of bilingualism. Rafiani (2009) researched codemixing which appeared in Hai magazine from 1997 until 2006. She investigated the amount of the English words used, the word classes, the forms and the motivations of the code-mixing. There were 1334 code-switches, out of which nouns were the most frequently code-switched items $(52,62 \%)$. The 
lexemes switched could remain in English, have Indonesian affixation, or have some syntactical changes. Interviews to the magazine journalists revealed that code-switches were done because of various reasons: referring to some concepts or ideas, attracting the audience's attention, or communicating ideas distinctively.

Amelia (2012) studied Indonesian-English codeswitches found in Femina and Kartini, two Indonesian women's magazines, March 2011 edition. The scope of her study was lexicon, register and syntax. She found that there were 947 incidents of the Indonesian-English code-switching out of her 76449 word-corpus. Intra-sentential code-switching was mostly employed $(95,1 \%)$, and noun was primarily code-switched $(87 \%)$. The other finding was that code-switching occurred in the registers of fashion and beauty. In addition, the Indonesian-English code-switches presented evidence that there was an agreement between the two languages in terms of the usage of words, phrases, and clauses.

Juliani (2012) studied code-switching performed by two teachers of one private school in Jakarta when they taught English in the classrooms. Her research revealed that the type of code-switching mostly used was inter-sentential code-switching $(63,95 \%)$, followed by intra-sentential code-switching $(27,91 \%)$ and lexical code-switching $(8,14 \%)$. The motivations for code-switching were to facilitate students' comprehension on the subject, attract students' attention to the subject taught, and take control of the class.

Siregar (2012) investigated the types, and the dominant type of code-mixing and code-switching in teen-lit novels, such as Fairish, Dealova and $\mathrm{Me}$ versus High Heels. The dominant type of code mixing was unit insertion with noun as the unit that was mostly inserted, and of code-switching was intersentential. Code-mixing and code-switching were used to adjust to circumstances, media of communication, topics, function and purposes of communication, and informality.

Wijana (2012) investigated the use of English in Indonesian adolescents' slang language. The data were taken from three slang dictionaries. It was found that the English used in the dictionaries was in the form of words, phrases and sentences. The English words were either used as the original form or mixed with the Indonesian words. Hence, the English words employed in the slang dictionaries showed that they had gone through either the process of nativization, semantic change, or literal translation. Some English words remained as they are, but actually led to abbreviations of Indonesian words whose meanings are not the equivalent of the original ones. For example, HIV stands for Hasrat Ingin Vivis [The Urge to Pee], AIDS for Anak Istimewa dengan Sejuta Pesona [A Special Kid with a Thousand Charms], and BMW for Body Mengalahkan Wajah [Body Beats the Face).

In this paper I report the investigation of how many English borrowings occurred compared to codeswitching, the types of borrowings, the frequency of code-switching occurrences, the types of codeswitching, and the lexical categories of the words borrowed. The Oxford Advanced Learner's Dictionary $8^{\text {th }}$ edition was used for classifying the lexical categories of the English words found in the data. The objective of my research is to reveal the role of English in Indonesian contemporary literature, one of which is the published collection of blog short stories.

\section{METHODS}

The data for this preliminary study are two books by Raditya Dika. The first book is a collection of 18 short stories entitled Babi Ngesot, Datang tak Diundang, Pulang tak Berkutang. Comprising 148 pages, it was published by Bukune in 2008. The second book, Manusia Setengah Salmon, consisted of 18 short stories in 258 pages, and was published by Gagas Media in 2011. All of the short stories were about the writer's personal experiences related to his family, friends, study, hobbies and work, and were formulated in a humorous style. The selected Dika's works (see Introduction) reflect an emerging linguistic phenomenon of Indonesian contemporary literary works which is marked by the transfer of spoken into written discourse. Hence, stories written in a blog can be turned into a book and attracted numerous readers (Ismono, 2009, para. 1-3). The first title has been reprinted twenty times within four consecutive years, and the second title had been reprinted ten times until 2012. The book's base language is Malay-Betawinese dialect and was mixed with the colloquial MalayBetawinese dialect and English.

After thoroughly reading the book, I recorded incidents of the English borrowing and classified its types based on Haugen's (1956) typology of borrowings (as cited in Romaine, 1995, pp. 55-60). Next, I also recorded occurrences and types of codeswitching according to Poplack's (1980) classification of code-switching (as cited in Romaine, 1995, pp. 122-124). Then, I calculated the number of borrowings and code-switches. 


\section{FINDINGS AND DISCUSSION}

The data showed that within the two titles there were 633 sentences that contained incidents of either borrowings or code-switching. The English borrowing accounted for $84 \%$ (712 incidents), while the intra-sentential code-switching comprised $11 \%$ (89 incidents), the inter-sentential code-switching 3\% (27 occurrences) and tag-switching encompassed 2\% (19 occurrences) (see Figure 1). The data showed that it was the lexical borrowing that was very commonly carried out by the writer, which lent support to Romaine's argument (1995) that "... lexical material is the most easily borrowed" (p. 64). To put it in another way, embedding words is more easily done than embedding phrases or sentences.

Hence, the writer predominantly used loanwords as many as 647 occurrences (93\%), whereas loanblends accounted for only $5 \%$ or 38 incidents, phonological adaptation $2 \%$ or 11 incidents (vide Figure 2). There was only one incident of loanshift. The explanation for phonological adaptation can be seen prior to sentence (10).

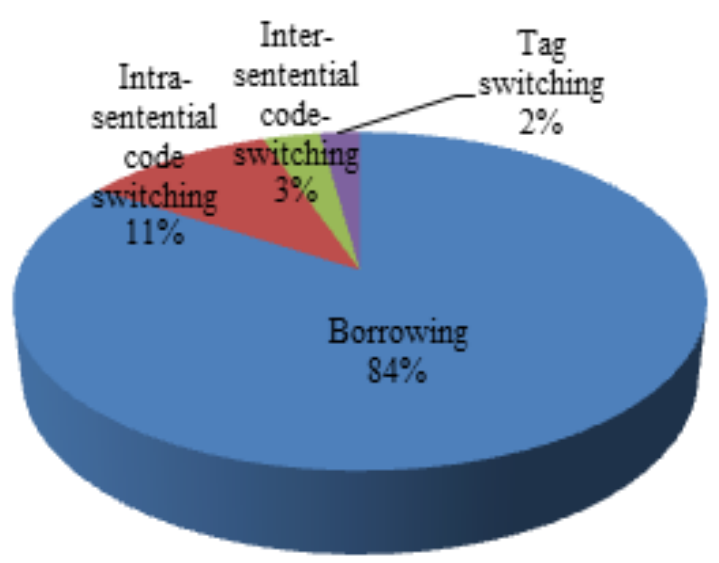

Figure 1. Incidents of borrowings and code-switching in Raditya Dika's Babi Ngesot, Datang tak Diundang, Pulang tak Berkutang and Manusia Setengah Salmon

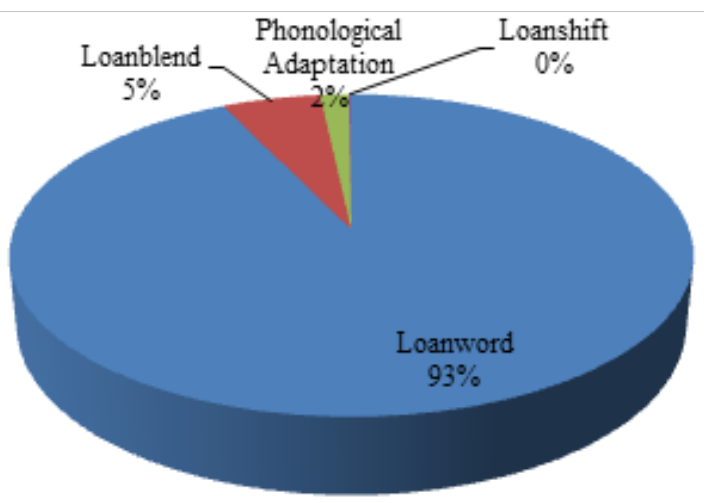

Figure 2. Types of borrowing in Raditya Dika's Babi Ngesot, Datang tak Diundang, Pulang tak Berkutang and Manusia Setengah Salmon
It turned out that the writer used loanwords for terms not available in Indonesian language as in (1), (2) and (3) below, as well as for those that have Indonesian equivalents, as in (4), (5) and (6), such as the Indonesian term for shock in (4) is terkejut, for game in (5) is permainan, and for expert in (6) is ahli. That proved that bilinguals do not code-switch because they have low competence in the two languages they speak. In fact, having knowledge and competence in two languages will result in the bilinguals" ". . . wider choice ..." of words when talking or speaking (Romaine, 1995, p. 143). All of the borrowed or codeswitched lexical items exemplified below are typed in bold-face. The following are the examples of the occurrences of loanwords:

(1) Maen baseball aja.

[Let's just play baseball.]

(2) Kemarin lo chatting ya?

[You chatted yesterday, didn't you?]

(3) Anime tentang apa ini?

[What kind of anime is this?]

(4) Gue shock.

[I was shocked.]

(5) Beberapa dari mereka maen Mario Party atau game-game olahraga.

[Some of them played Mario Party or sports games.]

(6) Ngomong-ngomong soal expert, di saat seperti ini juga, seharusnya ada nomor pemburu hantu yang bisa dihubungin.

[Talking about an expert, at this very moment there should be a ghost hunter I can call.]

The loanblends are exemplified in (7), (8), and (9) below. The lexical item supercepet in (7) was the combination of the English combined form super and the Malay-Betawinese colloquial adjective cepet. The word di-out-manuver in (8) was the blend of MalayBetawinese prefix $d i$ - with the English adverb out and the verb manoeuvre, which was written almost the same as its phonetic form. The item nge-date in (9) was the mix of the Malay-Betawinese colloquial prefix nge- and the English verb date.

(7) Kemungkinan besar Trisna terlalu sering mengupdate status Twitternya...

[It is very possible that Trisna updated her status at Twitter too often ...']

(8) 'Ingga, kamu bisa gak sih mainnya?' Edgar protes melihat Ingga yang dari tadi di-outmanuver sama gue.

['Ingga, can you play it?' Edgar was upset to see me manoeuvred my way to beat Ingga.]

(9) Salah satu situasi yang paling gue takutkan dalam nge-date adalah kalo si Cewek kesurupan.

[One of the most unwanted situations when I date someone is when my date is possessed by an evil spirit.] 
Furthermore, there were also several lexical items that were classified as phonological adaptation, for example, eniwei (from English anyway) as in (10), meibi (from English maybe) as in (11), bla bla bla and (from English blah blah blah) and oke (from English okay) as in (12). These incidents were included in Haugen's (1953) proposal of “ . . . the three stages in the process of phonological adaptation" of a word in another language to be used in one language (as cited in Romaine 1995, pp. 5960). Haugen argued that a foreign word, for example, the English word anyway, will be used as its original form by speakers of a language, say Indonesian, after the Indonesian speakers nativized it, i.e., using it as closely as possible to its 'phonetic form,' which is eniwei, accepted and used the word, then finally changed the nativized form back to the English form.

(10) Eh, lalu si Ringgo ngelanjutin, 'Meibi yes, Meibi no.'

[Then Ringgo said, "Maybe yes, maybe no."]

(11) Eniwei, kita langsung aja jawab pertanyaan kamu ya.

[Anyway, let's just answer your question. OK.]

(12) Oke, oke bagi sebagian orang kayanya cupu banget kenalan sama orang dari Friendster, ngajak kenalan bla bla bla.

[OK, OK, for some people it sounds so silly to meet a new guy through Friendster, blah, blah, blah.]

In addition to borrowing, the writer also employed inter-sentential code-switching, which is exemplified in (13), and (14), and intra-sentential code-switching as in (15), (16), (17), and (18). The incidents of both inter- and intra-sentential code-switchings in which the latter type is more difficult to perform, can be a clear evidence of the writer's competence of English (Romaine, 1995, p. 143). As a matter of fact, being an overseas student in Australia for several years, Raditya Dika did have a great access to English, which had made him a bilingual (Hamers \& Blanc, 2000, p. 6). Thus, according to Grosjean (cited in Baker, 2001, p. 101), even to monolingual readers of his books a bilingual like Raditya Dika frequently code-switched, indicating complex motivations of a bilingual's motivation to code-switch.

(13) Ketabrak pesawat terbang aja gitu lho. How unlucky could you be?

[Come on, you're just hit by a plane. How unlucky could you be?]

(14) This should be a restaurant. Kenapa gue harus masak makanan sendiri?

[This should be a restaurant. Why should I cook myself?]
(15) 'Satu hal yang bisa saya katakan pada kamu hari ini ... you won't die of cancer.'

[One thing that I can tell you today ... . you won't die of cancer.]

(16) Yang benar adalah: 'Jazz is like painting what's inside you.'

[The truth is: 'Jazz is like painting what's inside you.']

(17) Excuse me, can I gampar you punya pala?

[Excuse me, can I hit you on the head?]

(18) Untung gue gak nanggepin dia bilang, 'Okay, I will $S^{*}$ T down. Do you want me to jongkok or duduk while shitting?'

[Fortunately I did not respond him by saying, 'Okay, I will SH*T down. Do you want me to squat or sit while shitting?']

The tag-switching occurrences were also found, though the number was not significant. The sentences in (19), (20), and (21) have tag-switches:

(19) You know, restoran kayak gini atau Hanamasa gitu, di mana kita dikasih daging mentah, dikasih bumbu, dikasih kompor, terus masak sendiri.

[You know, a restaurant like this one or Hanamasa, we are provided with a stove and some marinated raw meat, and we should prepare the food ourselves.]

(20) Si Rene, gimana ya ngomongnya, well kalau mau disimpulkan sih begini : semenjak kejadian itu, dia udah jarang main ke rumah gue.

[That Rene, how shall I say it, well, in short, since the incident, she rarely came to my house.]

(21) By the way, Sab, lo cocok deh pake capuchon merah gitu, gue mengomentari gaya berdandan Sabrina yang tumben lagi bagus.

[By the way, Sab, the red capuchon suits you well, I commented on Sabrina's look, which, unexpectedly, was good.]

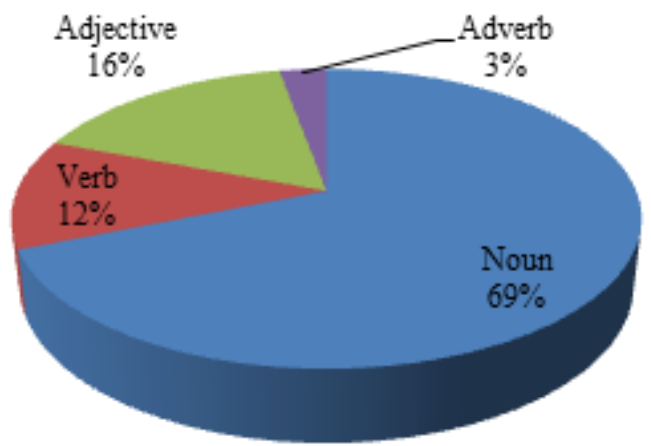

Figure 3. Lexical categories used in the English borrowing in Raditya Dika's Babi Ngesot, Datang tak Diundang, Pulang tak Berkutang and Manusia Setengah Salmon 
With regards to English borrowings, nouns were mostly borrowed (69\% or 382 words). The other lexical categories were adjectives 16\% (91 items), verbs $12 \%$ (66 words), and adverbs $3 \%$ (16 words) (see Figure 3). The finding seems to be in agreement with the research conducted by Poplack, Sankoff, and Miller (1988). They found that nouns were mostly borrowed by bilinguals because nouns had less integration to the matrix language, and showed the highest amount in English, compared to other function words (as cited in Romaine, 1995, pp. 6566). However, Poplack, Sankoff and Miller's argument that borrowing was a linguistic behavior performed by people of lower social class was not supported. The real social background of Raditya Dika as clearly described in all his books showed that he belonged to the higher social class.

\section{CONCLUSION}

The contemporary Indonesian literary discourse, particularly the teen fiction, and more specifically the blog short stories, can present an evidence of how Indonesian language has 'welcome' and 'befriended' English as one consequence of the increasing contact with English by means of media such as motion pictures, songs, print media, TV shows, and education in many fields of life in the past decades. English borrowings and code-switching with Indonesian can be easily found in Indonesian texts. Perhaps, it is because texts with heavy use of English will receive a better appreciation than those that do not. This fact is evident in Raditya Dika's collections of short stories, and other Indonesian young writers' best-selling fictions termed as chic-lit and teen-lit (Djenar, 2008, pp. 243-244). However, the frequent English borrowings and code-switching in one of his books that I studied have indicated a more significant role of English in the Indonesian contemporary literary work. It seems that the English borrowings and the Indonesian-English code-switching, together with the colloquial Indonesian, are the "conventionalized codes" of today's fiction work. Thus, the Betawi-Malay dialect together with English may have functioned as the semi 'lingua franca' for Indonesian teenage writers and readers in spite of the fact that English is merely a foreign language: Kachru's Expanding Circle (Crystal, 2003, p. 60). The recently mentioned linguistic phenomena can also be an important linguistic distinguishing marker between the contemporary and the non-contemporary Indonesian literature (the 1920 Generation, the 1945 Generation, the Pujangga Baru Generation, the 1966 Generation, the 1980 Generation, and the 1990 Generation) besides the theme, setting and other aspects of literary works.

\section{SUGGESTION}

This study can be extended to research on the motivation of borrowings and code-switching by the author, and to the extent to which English borrowings keep their meanings once they enter the Indonesian vocabulary; hence, the seed of a collection of the latest Indonesian words (as the Indonesian dictionary should be officially published by the Ministry of Education). Besides that, a further investigation with regards to the English errors produced by the writer may be conducted. Also, the degree to which the colloquial Betawi-Malay and Standard Indonesian code-switching have produced humorous effects, which have been the source of attraction and pleasure for the readership, may be worth researching as it can be a valuable contribution to the study of the development of Indonesian language.

\section{REFERENCES}

Amelia. (2012). Indonesian to English code-switching in two women's magazines: Structural, grammatical, register, and semantic classifications. [Unpublished master's thesis]. Universitas Katolik Indonesia Atma Jaya, Jakarta. http://lib.atmajaya.ac.id/default.

Attarriba, J. \& Morier, R. G. (2006). Bilingualism: Language, emotion, and mental health. In T. K. Bhatia \& W. C. Ritchie, (Eds.), The handbook of bilingualism (pp. 250-281). Oxford: Blackwell.

Baker, C. (2001). Foundations of bilingual education and bilingualism ( $3^{\text {rd }}$ edition) Clevedon: Multilingual Matters.

Bloomfield, L. (1935). Language. London: George Allen \& Unwin Ltd.

Bunanta, M. \& Hayon, N. G. (1993). Indonesian literature published by publicshers other than Balai Pustaka before the war. [Unpublished paper]. Jakarta: Program Studi Kesusasteraan PPS Universitas Indonesia. Retrieved from http:/lib. atmajaya.ac.id/Uploads/Fulltext/34018/Sastra\% 20Indonesia $\% 20$ sebelum $\% 20$ Perang $\% 20 \mathrm{di} \% 2$ 0Luar\%20Balai\%20Pustaka.pdf

Crystal, D. (2003). English as a global language (2 $2^{\text {nd }}$ edition.). Cambridge: Cambridge University Press.

De Klerk, V. (2006). Codeswitching, borrowing and mixing in a corpus of Xhosa English. The International Journal of Bilingual Education and Bilingualism 9(5), 597-614. Retrieved from http://eprints.ru.ac.za/ 363/1/codeswitching_De_Klerk.pdf

Dika, R. (2005). Kambing jantan: Sebuah catatan harian pelajar bodoh [Billy: A diary of a stupid pupil]. Jakarta: Gagas Media. 
Dika, R. (2006). Cinta Brontosaurus [Brontosaurus Love]. Jakarta: Gagas Media.

Dika, R. (2007). Radikus makan kakus: Bukan binatang biasa [Radikus eats a toilet: An extraordinary species). Jakarta: Gagas Media.

Dika, R. (2008). Babi ngesot, datang tak diundang, pulang tak berkutang [A disabled pig: Coming uninvited, leaving with no bra]. Jakarta: Bukune.

Dika, R. (2010). Marmut merah jambu [A pink marmot]. Jakarta: Bukune.

Dika, R. (2011). Manusia setengah salmon [A halfsalmon man]. Jakarta: Gagas Media.

Djenar, D. N. (2008). On the development of a colloquial writing style: Examining the language of Indonesian teen literature. Bijdragen tot de Taal-, Land- en Volkenkunde (BKI) 164 (2/3), 238-268. Retrieved from http://www.kitlvjournals.nl/index.php/btlv/article/viewFile/3562/ 4322

Edwards, J. (2006). Foundations of bilingualism. In T. K. Bhatia and W. C. Ritchie (Eds.). The handbook of bilingualism (pp. 7-31). Oxford: Blackwell.

Grosjean, F. (2008). Studying bilinguals. Oxford: Oxford

Grosjean, F. (2006). Studying bilinguals: Methodological and conceptual issues. In T. K. Bhatia \& W. C. Ritchie (Eds.). The handbook of bilingualism (pp. 32-64). Oxford: Blackwell.

Hamers, J. F. \& Blanc, M. H. A. (2000). Bilinguality and bilingualism. Cambridge: Cambridge University Press.

Ibhawaegbele, F. O. \& Edokpayi, J. N. (2012). Codeswitching and code-mixing as stylistic devices in Nigerian prose fiction: A study of three Nigerian novels. Research on Humanities and Social Sciences, 2 (6), 12-18. Retrieved from http://www. google.com/url?sa=t\&rct=j\&q=\&esrc=s\& source= web\&cd=15\&ved=0CEQQFjAEOAo\&url=http $\% 3 \mathrm{~A} \% 2 \mathrm{~F} \% 2 \mathrm{Fwww}$.iiste.org\%2FJournals\%2Fi ndex.php $\% 2$ FRHSS $\% 2$ Farticle $\% 2$ Fdownload $\%$ 2F2376\%2F2375\&ei=y7aYUI34F4fmrAe-yo CIBw\&usg=AFQjCNF_iFk4qDRmrq8ZBUR OWCS_9-Q0UA.

Ismono, H. (2009, January 7). Raditya Dika: Semua berawal dari kesuksesan "ngeblog." Kompas. com. Retrieved from http://megapolitan. kompas. com/read/2009/01/07/10305623/Raditya.Dika.S emua.Berawal.dari.Kesuksesan.Ngeblog

Juliani, E. (2012). Code-switching by kindergarten teachers at Tarakanita II kindergarten school [Unpublished master's thesis]. Universitas Katolik Indonesia Atma Jaya, Jakarta. Retrieved from http://lib.atmajaya.ac.id/Uploads/ Fulltext/180682/SPM\%2001\%20ELVI.pdf
Kang, H. (2008). Proceedings of the 20th North American Conference on Chinese Linguistics (NACCL-20), 2(999-1010). Ohio: The Ohio State University. Retrieved from http://naccl.osu. edu/sites/naccl.osu.edu/ files/66_kang-h.pdf

Lazuardi, E. A. (2008, November 28). Ruang baru anak muda [Young people's new space]. Kompas.com. Retrieved from http://entertainment. kompas.com/read/2008/11/28/1050125/Ruang.Ba ru.Anak.Muda

Leksono, N. (2008, December 3). Mumbai, jurnalisme dan masa depan internet [Mumbai, journalism and the future of the Internet]. Kompas.com. Retrieved from http://nasional. kompas.com/read/2008/12/03/07143887/ mumbai.jurnalisme.dan.masa. depan. internet.

Lorania. (2012). The analysis of English borrowing words in Indonesian political terminology [Unpublished undergraduate's thesis]. Universitas Islam Negeri Syarif Hidayatullah, Jakarta. Retrieved from http://repository.uinjkt.ac.id/ dspace/ handle/123456789/2364

MacSwan, J. (2006). Code-switching and grammatical theory. In T. K. Bhatia \& W. C. Ritchie (Eds.). The handbook of bilingualism (pp. 283-311). Oxford: Blackwell.

Mahayana, M. S. (1997). Indonesian authors in 1950s: An image creation. Jurnal Studi Indonesia, (7). 2, 1-18, Retrieved from http:/lib.atmajaya.ac.id/ Uploads/Fulltext/147867/artikel/Maman\%20S \%20Mahayana.pdf

O'Malley-Madec, M. (2007). How one word borrows another: The process of language-contact in two Irish-speaking communities. The International Journal of Bilingual Education and Bilingualism, 10 (4), 494-509. Retrieved from http:/lib.atmajaya.ac.id/Uploads/Fulltext/174400/ artikel/Vol.\%2010,\%20No.\%204,\%202007,494 \%20\%E2\%80\%94\%20509.pdf

Rafiani, R. (2009). Indonesian-English code-switching in teenagers magazine: A review of 10-year development [Unpublished master's thesis]. Universitas Katolik Indonesia Atma Jaya, Jakarta. Retrieved from http://lib.atmajaya.ac.id/ Uploads/Fulltext/164768/List\%20of\%20Conten ts-final\%20revision.pdf

Renata, I. (2008). A descriptive study of codeswitching: A case study of a radio program [Unpublished undergraduate's thesis]. Universitas Katolik Indonesia Atma Jaya, Jakarta. Retrieved from http://lib.atmajaya.ac.id/ Uploads/ Fulltext/149941/Irene\%20Renata\%27s\%20Und ergraduate\%20Theses.pdf

Romaine, S. (1995). Bilingualism ( $2^{\text {nd }}$ edition.). Oxford: Blackwell. 
Rudi prepares movie on blogger (2008, October 13). The Jakarta Post. Retrieved from http://www. thejakartapost.com/news/2008/10/13/rudi-prepares-movie-blogger.html

Siregar, S. S. (2012). Code-mixing and codeswitching in teen lit novels [Unpublished master's thesis]. Universitas Negeri Medan, Medan. Retrieved from http://digilib.unimed. ac.id/UNIMED-Master-1278/1278.

Sneddon, J. (2003). The Indonesian language: Its history and role in modern society. Sydney: UNSW Press.

Srikandi, C. N. (2010). Borrowing in the translation of D. H. Lawrence's Lady Chatterley's Lover into Indonesian [Unpublished undergraduate's thesis]. Universitas Sumatera Utara, Medan. Retrieved from http://repository.usu.ac.id/bitstream/123456789/13423/1/10E01100.pdf.
Widyaningsih, M. D. (2011). The phonological changes of loanwords in Indonesian [Unpublished undergraduate's thesis]. Universitas Gunadarma, Depok. Retrieved from http://papers.gunadarma.ac.id/index.php/ letter/article/viewFile/629/586.

Wijana, I. D. P. (2012). The use of English in Indonesian adolescent's slang. Humaniora, 24, 315-323. Retrieved from http://www.google. com/url?sa=t\&rct $=\mathrm{j} \& \mathrm{q}=\&$ esrc $=$ s\&source $=$ web $\& \mathrm{~cd}=9 \& \mathrm{ved}=0 \mathrm{CGUQFjAI} \& u \mathrm{rl}=\mathrm{http} \% 3 \mathrm{~A} \% 2 \mathrm{~F}$ $\% 2$ Fjournal.ugm.ac.id\%2Findex.php\%2Fjurnalumaniora $\% 2$ Farticle $\% 2$ Fdownload $\% 2$ F1373 \%2F1165\&ei=EMrGUM_UB4vtrQeJxoGQAw \&usg=AFQjCNEwDypkH0wooXXOWLqflSK rP6Jhiw\&bvm=bv.1354675689,d.bmk in ESL academic writing. In J. Flowerdew \& M. Peacock (Eds.), Research perspectives on English academic purposes (pp. 117-131). Cambridge: Cambridge University Press. 